\title{
Study on Navigation College International Campus Construction-- Take the example of Shandong Jiaotong University
}

\author{
Yuan Gao \\ Shandong Jiaotong University, Weihai, China
}

Keywords: maritime applied university; international campus; main problems; improvement measures

\begin{abstract}
International campus construction is an important topic in the comprehensive reform of marine application universities. This paper analyzes the current international development of maritime applied universities, and sorts out the problems existing in the construction of international campuses. This paper attempts to construct a strategy for international campus construction, and proposesimprovement measures from the aspects of school strategy, teacher team building, and building campus culture.
\end{abstract}

\section{The research background}

In 2012, the Ministry of Education and the Ministry of Transport "Several Opinions on Further Improving the Quality of Maritime Education" clearly pointed out that "the introduction of foreign advanced maritime education resources, learning and learning from the advanced concepts and experiences of maritime education in developed countries, and the development of Sino-foreign cooperative education in accordance with the law. Supporting maritime colleges to recruit overseas students, conduct overseas education, and improve the international influence of maritime education in China. This emphasizes that maritime applied universities should accelerate the pace of internationalization and train qualified maritime international talents. Taking the Weihai Campus of Shandong Jiaotong University as an example, this paper discusses the current situation and existing problems of the international campus construction of China's maritime applied universities, and proposes corresponding strategies and solutions.

\section{The research status and main problems}

At present, Shandong University of Communications Weihai Campus has carried out some effective explorations on the road of international campus construction: (1) The school supports the maritime professional teachers to work on the ship while retaining the ranks, and hires the international ocean captain with rich experience in the sea. And the chief engineer to teach at the school to build a double-skilled faculty; (2) to carry out order-based talent training according to the actual needs of international large shipping companies and international cruise ships. (3) Some of the professional courses of cross-cultural communication in the School of Navigation, such as the Maritime Law, have begun the construction of bilingual courses. (4) The school organizes a series of activities, such as English speech contests and English song contests to improve students' English expression skills. Encourage students to establish English corners and spoken language groups to improve intercultural communication skills. During the exploration process, we also found some problems and deficiencies: (1) The maritime graduates have poor intercultural communication skills, and the oral English level is not high. Boys are afraid to open their mouths because of their shame and lack of interest in English. Practicing English, in many cases, effective communication is not possible. (2) The construction of the faculty of the maritime profession is far from being internationalized. At present, college English teachers are unable to teach sailing courses because of professional shortcomings. The maritime professional teachers have a low level of oral English and their pronunciation is not accurate. It is impossible to carry out bilingual courses smoothly. (3) It is difficult to carry out Sino-foreign cooperation in running schools. Students who are eligible to 
participate in Sino-foreign cooperative education to study abroad need to meet relevant requirements in terms of professional competence, interest in learning, English proficiency, and family economic conditions. The number of students who can meet the above conditions is small.

\section{The specific measures for the construction of international campus in marine application universities}

\subsection{Incorporate “campus internationalization” into the school's major development strategy and give strong support to people's financial aspects}

In order to achieve substantial breakthroughs and progress in the internationalization of campuses, the leadership of maritime applied universities must pay attention to it and put the construction of international campuses at the top of the strategic development of schools. We will make overall arrangements for the improvement of various systems and open green channels in all aspects of manpower, financial resources and material resources. Taking the Weihai Campus of Shandong Jiaotong University as an example, the school clearly listed the international campus construction as one of the major development strategies of the campus in the "13th Five-Year Plan", and plans to establish the Weihai Campus International Exchange Center. So far, our school has made certain achievements in international exchanges and cooperation, which can be used for reference.

The International Exchange and Cooperation of the School of Navigation is divided into two categories, one is degree education cooperation. The college has already reached a cooperation intention with the University of Linnaeus (Kalmar Campus) in Sweden and the University of Portsmouth in the United Kingdom to jointly carry out degree education. The other category is higher vocational education cooperation. As the global seafarers' training is based on the International Maritime Organization's STCW Convention, in order to introduce advanced education and training concepts and build a high-level crew training base, the College cooperates with well-known shipping institutions in Europe and Asia to develop polar training and other projects before the crew is employed. Training. The German Ship Operation Engineering Committee has reached a consensus with the School of Ship and Marine Engineering on the exchange of teachers, mutual recognition of credits, and the course of the " $3+1 "$ joint training project for ship electrical and electronic engineering. The engineering " $2+2 "$ dual degree program cooperates.

\subsection{Strengthening the construction of international faculty}

Employing captains and chief engineers from developed countries in the world's shipping industry to work part-time or long-term teaching; increase the hiring of foreign teachers; hire experts with outstanding achievements in the industry as honorary professors or visiting professors; participate in international maritime professional teachers The conference provides information and financial support. Strengthen the English training of maritime professional teachers, encourage teachers to participate in IELTS and other overseas examinations, and conditionally consider visiting abroad. It is possible to consider an English training course for foreign professors in the summer and winter, and teach in English to further improve the English speaking level of the maritime professional teachers. In addition, university English teachers who have spare capacity can be encouraged to actively participate in maritime training and strengthen professional learning.

\subsection{Creating an international campus environment}

To create an internationalized campus environment, we must not only support it from the policy, but also use our specific implementation plan to move our minds. The more operational ideas are: (1) To realize the bilingualization of campus markers. All signs, laboratories, and landscapes on the campus are bilingual; (2) the school's external publicity materials, admission manuals, and school official website for bilingual construction in Chinese and English; (3) can refer to the practice of domestic and foreign language colleges and universities, and hold English every year. Voice tone contest, drama contest, English National Culture Week, etc. For example, the drama competition 
requires the preparation of gorgeous costumes, realistic props, exciting stories in advance, close to the interests of current college students, the best male and female protagonists, the best male voice, the best director, the best script competition can improve students' English cross Cultural communication concerns.

\section{Summary}

The maritime application-oriented university should regard the construction of international education park as an important mission of university development, and design and define the development strategy. High-level applied universities should have very active international exchanges and cooperation, and their internationalization should be unique and reach a high level. Although there are some problems in the process of international campus construction, the maritime applied universities are actively creating creative conditions, and we can explore an effective way to suit the characteristics of the school.

\section{References}

[1] Jin Wei. Harmony: Facing the Internationalization of Higher Education[J]. Higher Education Development and Evaluation, 2008(7):7-13.

[2] Li Keyong. On the Connotation and Implementation Strategy of University Internationalization[J]. University Research and Evaluation, 2007(10): 40-42.

[3] Wang Ying. Research Trends of University Internationalization in Recent Ten Years[J]. Higher Education Management, 2008(3): 47-50.

[4] Cheng Long, Chen Guofeng. The Role of Volunteer Spirit in the Construction of Zhou Culture in Universities[J]. Management Observatory,2014(31):146-151.

[5] Liu Xinyan, Zhao Wenlei, Gao Ming. Practice Exploration of International Talents Training Mode in Colleges and Universities[J]. Navigational Education Research, 2014(3): 51-53.

[6] The Central Committee of the Communist Party of China and the State Council. Opinions on Strengthening and Improving the Ideological and Political Work of Colleges and Universities in the New Situation [R].2017.2.27.

[7] Zhang Yan. Beyond History and Spontaneity Improving the Function of Campus Culture Education[J]. China Higher Education, 2005.19.

[8] Pan Yiyuan. New Higher Education [M]. Beijing: Beijing Normal University Press, 1996.590.

[9] Meng Kexin. Comparison and Enlightenment of Campus Culture Construction between Chinese and American Universities[J]. Journal of Shenyang Agricultural University (Social Science Edition), 2013.09.

[10] Cheng Li. On the Connotation of Campus Culture in Colleges and Universities [J]. The Window of Management, 2003.05.

[11] National Medium- and Long-Term Education Reform and Development Plan (2010-2020) [N]. Guangming Daily, 2010-07-29.

[12] Wang Banghu. Campus Culture Theory [M]. Beijing: People's Education Press, 2000.

[13] Zhejiang Higher Education Internationalization Development Annual Report (2015) [R]. Zhejiang Provincial Education Department website document reading. 